


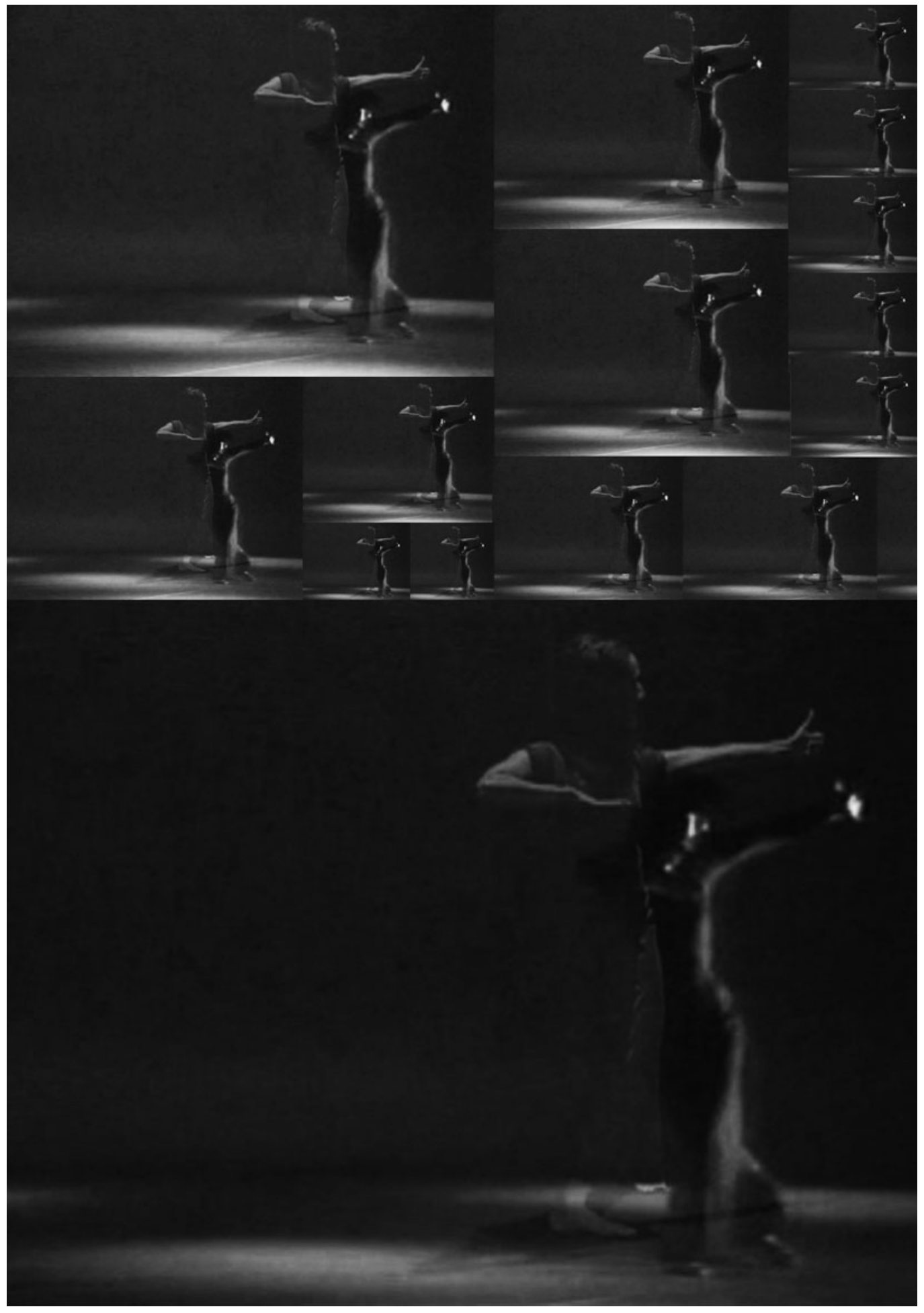




\title{
Inheriting Dance's Alternative Histories
}

\author{
Kate Elswit
}

I

$\mathrm{t}$ is October 2012, and choreographer Rani Nair and I are deliberating the last scene of Future Memory, which will soon premiere at Danstationen in Malmö, Sweden. A decade ago, Nair reconstructed Dixit Dominus, a 1975 collaboration between German choreographer Kurt Jooss and Swedish-based Indian dancer Lilavati Häger. ${ }^{1}$ Although Jooss is often central to narratives of twentieth-century dance theater, the solo is not well recognized within his oeuvre, because it was made for Häger almost ten years after what was considered to be his last choreography. ${ }^{2}$ After Häger's death in 2002, her husband, the impresario and dance champion Bengt Häger, passed it on to Nair, telling her "when you inherit the piece, you inherit everything that goes with it." Yet, wearing Häger's costumes and hearing stories about her, while attempting to do her movement, made Nair feel farther from, rather than closer to, Dixit Dominus and its original creators. As a second-order performance-a performance about a performance-Future Memory explores how else she might engage with that inheritance.

Having just watched a full run of the work-in-progress, I am troubled that, no matter how far the previous sections go in constructing a constellation of new scenarios from costumes, music, memories, and documentation associated with Dixit Dominus, the current ending fetishizes those traces: the stage empty other than a microphone that sits on a tape recorder, amplifying a rehearsal tape from which Jooss's elegant, accented voice counts and sings over the Händel cantata. We are enchanted by how it fills the white space with a score of ever-changing numbers and instructions: "one and two and three, four; one, two, three, four ... swim, two, three, four, five, six, seven, eight ... da-da-da, step, two, three...." But my concern is that to play it alone risks privileging the past at the last minute. Instead, our task is to work with the tape un-elegiacally; rather than finishing on loss, we need to reframe the scene in a way that allows audiences to see the tape as we do-a trace of an overlooked past experiment in hybrid dance practice brought into coexistence with the present through another such experiment, one that locates the multiple times and places it brings together, at the same time as it allows something new to be "re-membered" in the empty space.

Kate Elswit is Lecturer in Theatre and Performance Studies at the University of Bristol. Previously, she was at Stanford University as a postdoctoral fellow in the Andrew W. Mellon Fellowship of Scholars in the Humanities, and she has also taught at CalArts, Laban, and the University of Cambridge, where she received her Ph.D. She was awarded the Gertrude Lippincott Award from the Society of Dance History Scholars and the Sally Banes Publication Prize from the American Society for Theatre Research, and her essays have been published in TDR: The Drama Review, Theatre Journal, Modern Drama, Art Journal, Performance Research, and in the edited collection New German Dance Studies. Her book Watching Weimar Dance is forthcoming this summer with Oxford University Press. She is a choreographer, dramaturg, and curator. 
The last fifteen years have been full of "reenactments," "recreations," and "reinventions," to name a few classifications, all preoccupied with re-using the material of past performances. ${ }^{3}$ Describing what he calls the "archival impulse" in contemporary art, Hal Foster suggests that such work fulfills a specific function: the artist-as-archivist not only considers and reorders but also produces materials, in doing so underscoring the nature of all archival materials as "found yet constructed, factual yet fictive, public yet private" $(2004,5) .{ }^{4}$ Yvonne Hardt observes about trends in dance that on European stages, "artists have discovered the past as a playground for the present" $(2012,218)$, a phrase that seems significant. Earlier debates concerning dance reconstructions revolved around questions of fidelity toward characteristics of a perceived "original" versus allowing the past to mature (for example, Rubidge 1995). By contrast, the newer set of "re"-performances has tended to focus on what can be made in the present using the past. They posit understandings of history that are produced, as Gerald Siegmund puts it, between actively acquiring sources and passively allowing oneself to be affected by that which must remain unavailable within them $(2010,26)$.

The longer I have spent with Future Memory, the more it has clarified the potential, but also the very precarious nature, of working with such creative strategies at the intersection of multiple contested legacies. Dixit Dominus has often been seen as an addendum that does not fit neatly into the canon of dance history. Likewise, the intertwined German and Indian dance practices that grounded the Dixit collaboration were each themselves reinvented during the twentieth century. One of the challenges of returning to those materials today was how to resist flattening the distinct temporalities that we negotiated, in particular with regard to practices that have their own histories of redoing. Future Memory develops an alternative history in which a "minor" work takes ten years of another artist's life, and where the roles of insider and outsider are more complicated than we might think.

This essay is not entirely a view from inside, since I consider my role as dramaturg to be in part that of the "first spectator," an acute observer and interlocutor who watches over and over and articulates what she sees. Nor is it, however, entirely from outside, because I have, through this process of observing, actively taken part in shaping the work about which I now write. Rather the essay's shifts

Photo 1. 1975 promotional image of Kurt Jooss and Lilavati Häger rehearsing for Dixit Dominus. Taken by Folke Hellberg for Dagens Nyheter. Courtesy of Rani Nair.

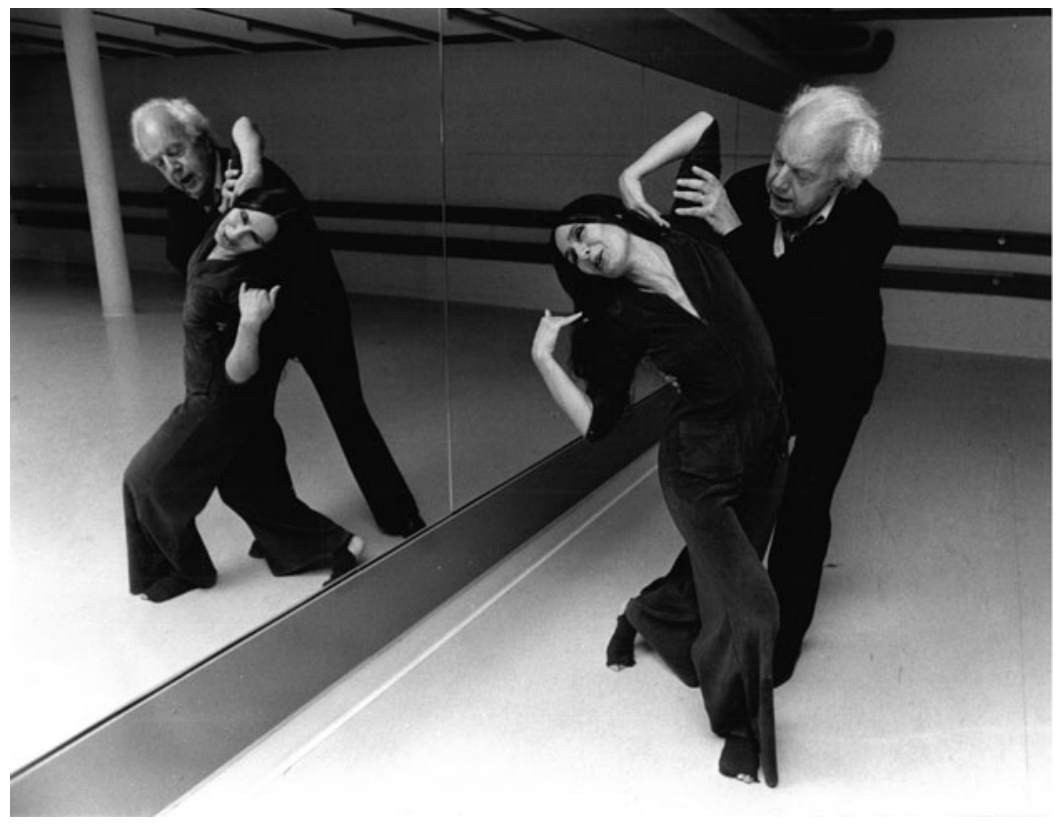


from the anecdotal to the critical mark an experiment in "writing alongside" - an attempt to give written form to a series of thoughts that have developed with, through, and sometimes even against the process of making Future Memory, in a manner that combines multiple registers of research. ${ }^{5}$ I start in close proximity to the studio and stage, with decisions we made to create a performance that dealt less with the choreographic movement of Dixit Dominus, than movement in the sense of the dance's circulation among multiple protagonists. From there, I approach some larger questions that have arisen regarding how contemporary performance can rework the past, in particular the stakes of balancing the historical specificity of contested legacies with the global nature of their interconnections.

\section{Staging Inheritance: From Dixit Dominus to Future Memory}

Kurt Jooss's last dance Dixit Dominus was made over a period of five weeks as a solo for Lilavati Häger, who had always wished she could dance the role of the guerilla or partisan in his famous Green Table (Photo 1). That Dixit itself already began as a kind of reworking time is suggested by a conversation in which Häger proposes to Jooss that she would have been one of his dancers, had they met earlier (Sjögren 1975). Set to part of Händel's "Dixit Dominus," a filmed version from 1977 shows a piece in which stylistic features of Jooss's modern movement intertwine with Häger's training in multiple classical Indian forms. The choreography was themed around a "message" Jooss found: "What you take for yourself, shall be lost to you-what you give, will remain with you forever" (Jooss/Westerberg 1977). It consisted of two parts: the first aggressive, greedy, and full of "false heroism," in contrast with the second that was lyrical and based on giving (see Häger's description in Pikula 1981). The movement of the piece from Jooss to Häger to Nair further extends this underlying idea. Bengt Häger knew that his wife had always wanted to pass on the work, and that after seeing Nair dance for British Asian choreographer Shobana Jeyasingh shortly before her death, Lilavati Häger mentioned having found the dancer for Dixit Dominus. Jooss's concept, in turn, also structures the grounding question of the Future Memory project: how does one accept a gift and care for it by finding new ways to pass it on? To do nothing before giving it away would be to reject the gift, whereas to do too much risks "taking" for oneself.

Learned from film and coached by Bengt Häger, Nair's reconstruction toured between 2003 and 2006, and was presented, among other places, at Centre National de la Danse in Paris and the

Photo 2. A 2006 film of Nair's Dixit Dominus reconstruction superimposed onto Häger's 1977 television performance.

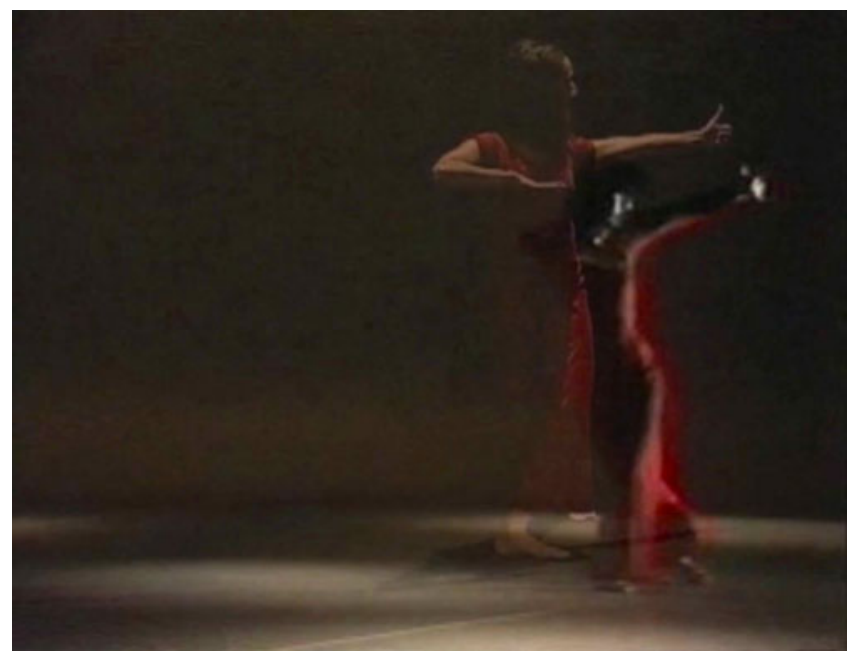


Hanoi Opera House. It was relatively faithful to the shapes and timing of the older movement, with controlled doses of intentional and unintentional anachronism (Photo 2). Bengt not only gave Nair his wife's costumes, but he also traveled during the rehearsal period in order to give his approval, and eventually requested that Nair dance it at his funeral. That said, it is worth pointing out that even this version of Dixit Dominus involved significant decision-making. Writing about the reconstruction, Lena Hammergren suggests that "both vocabularies are given equal weight, and [Nair] performs the solo as a dialogue between aspects of two worlds that are never fully joined together-as if addressing the issues of multiculturalism versus integration, which were hotly debated in Swedish politics and media at the time" $(2009,27)$. Yet, despite this, Nair had tried to smooth over the multiple logics of time in reconstructing the unforgiving movement. For example, the tension of Häger's body in the floor sections was something Nair attempted to update by adding more weighted qualities, and yet she did not want to fully commit to the release-based relationship to the floor that may be read as "better" in contemporary dance contexts. Because Nair was younger than Häger at the time of Dixit, there were also questions regarding whether to perform it as it was created for a dancer past her prime who was never entirely happy with her own performance, or whether to perform the dance Lilavati Häger would have wanted to dance.

Nair and I were first introduced by a mutual friend because she was unsatisfied with the "successful" reconstruction, and wanted help thinking about other ways to keep working with this gift. I fell in love with the potential of the nascent project at a moment when she was struggling to locate it in a way that would generate interest and funding. We conversed intermittently though various showings between 2009 and 2011 in Belgrade, Hamburg, and Stockholm, among other places. In the early stages of Future Memory, Nair's challenge was separating herself from Häger. I eventually proposed she try writing Häger letters, which she did in Swedish and English. They confided things and asked questions, not only about Jooss and the dance, but also about living with mixed heritage, about Häger's love life, and even what she liked to eat. ${ }^{6}$ Through the letters, Nair started to develop a sense of compassionate distance from the older dancer. She also began to stage herself as various figures who might bridge the gaps between herself and the many protagonists of Dixit Dominus, filling my inbox with images as the English-Sri Lankan rapper M.I.A., as Scheherazade next to Bengt Häger (Photo 3), and one with a wig and moustache that arrived under the subject "Went lookin for Kurt Jooss, found Frank Zappa." The personas and letters showed what had been missing from the earlier reconstruction: the complex network that the piece engendered not only between the two women, but also with Jooss, Bengt Häger, and others-relationships which had been overwhelmed when Nair dressed up as Lilavati Häger or tried to take on her movements too perfectly.

Photo 3. Webcam shot of Nair and Bengt Häger in Häger's apartment, ca. 2008-2009.

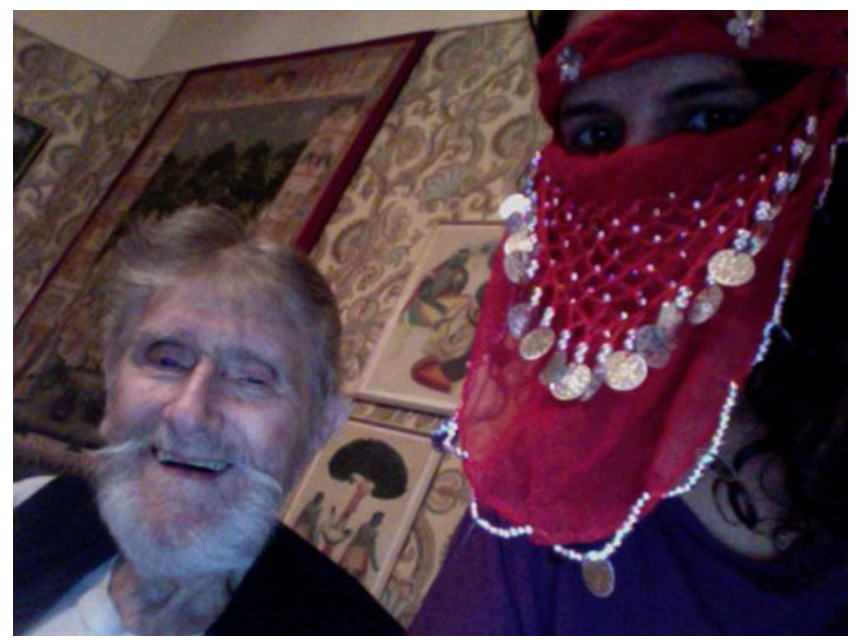


By the time we received funding from Konstnärsnämnden and Kulturrådet in 2011-2012 to develop Future Memory as an evening-length piece that would play in a gallery-type space, we understood the need to return to Dixit Dominus differently. ${ }^{7}$ To extend Dixit's circulation as a gift- to receive the inheritance in a manner that does not simply take, but rather continues toward passing on-Future Memory needed to be not about the dance as movement in itself, but about the movement of the dance. While the choreography and performance remain important, at the core of the new piece is the exchanges that occurred through the work: between different traditions of dance that have their own contested legacies; between the choreographer and first solo performer, as well as her husband who passed the dance along; between the various artifacts that remain and those who encounter them today and, like Nair and myself, even build new relationships through them. A critic from Svenska Dagbladet wrote: "It is a gift to inherit something significant, but it can also mean a lot of pressure. You may even need to distance yourself and revolt.... And capture the time elapsed between the generations ... The dancer Rani Nair does all this in the solo 'Future Memory,' a wonderful, soul-searching, smart, funny and deeply personal act” (Angström 2014). This balance of what a preview called "humor, warmth, and intellectual sharpness, all in one" is something Nair and I have worked to maintain. We looked for a register that resonates with the intimate nature of the stories surrounding Dixit Dominus, while still keeping some of their secrets, as well as our own.

Just before the premiere, an interviewer asked whether I thought Kurt Jooss would be pleased with Future Memory. I suspect no choreographer could help but appreciate when someone spends so long caring for one of their dances, particularly one like Dixit Dominus. Jooss's biographer Patricia Stöckemann gives his last dance only a few lines of an immaculate book, dismissing Dixit as something that Jooss was cajoled into doing "out of friendship," resulting in "a 1976 dance with a touch of Indianness [that] remained in its unadorned simplicity nothing more than marginalia in Jooss's creations" $(2001,397) .{ }^{8}$ When I pointed this out, Nair told me that, in 2005 when she toured Dixit in Germany, she was confused because people would tell her afterward "this is not the real Jooss." We also ran into issues finding funding for Future Memory, until we could articulate that there was something important about the piece's relative obscurity. Whereas Nair had struggled earlier with Dixit Dominus's ambiguous place outside the canon, Future Memory embraces that position. And yet that erodes a little more each time Nair performs it, each time a new audience spends an hour with the dance's traces.

One of the throughlines in Future Memory is a series of memory tasks that stages Nair's intimacy with the material in a manner that is at once authoritative and eccentric. The evening begins with her in a chair upstage, absorbed in an iPhone video of the reconstruction in Paris. We do not see the recording. We only hear her "singing the score" of the full-length piece, counting off the timing of the movements in a combination of vocalizations familiar from Indian dance practices and her own, more idiosyncratic locutions. Later, she balances in a headstand to recite the text of a letter she received from the Carina Ari Library years ago, loaning her the now deteriorating videotape, commenting on the condition and asking her to please return it when she is done. In a section called "Memory of Lila," Nair sits cross-legged on top of a television, describing without seeing what is happening as Lilavati Häger performs Dixit Dominus (Photo 4). She demonstrates her favorite mudra as Häger does it; remarks on the effect of Vaseline on the camera lens in another; and jokes that she thinks of a particular moment as a kind of Indian disco dance. When she gets down toward the end, she blocks our view of the television as she explains that the dance does not actually end in the way the documentation suggests. Yet another exercise in remembering comes with a verbatim section in which Nair voices an interview with Jooss about Dixit. Although we hear his words only as she receives them through headphones, her face, head, and hands duplicate the small gestures that we see Jooss making on the television behind her.

In each of these memory tasks, familiarity remediates documentation, drawing attention to the materiality of the archival artifacts through, rather than despite, Nair's performance. During the 


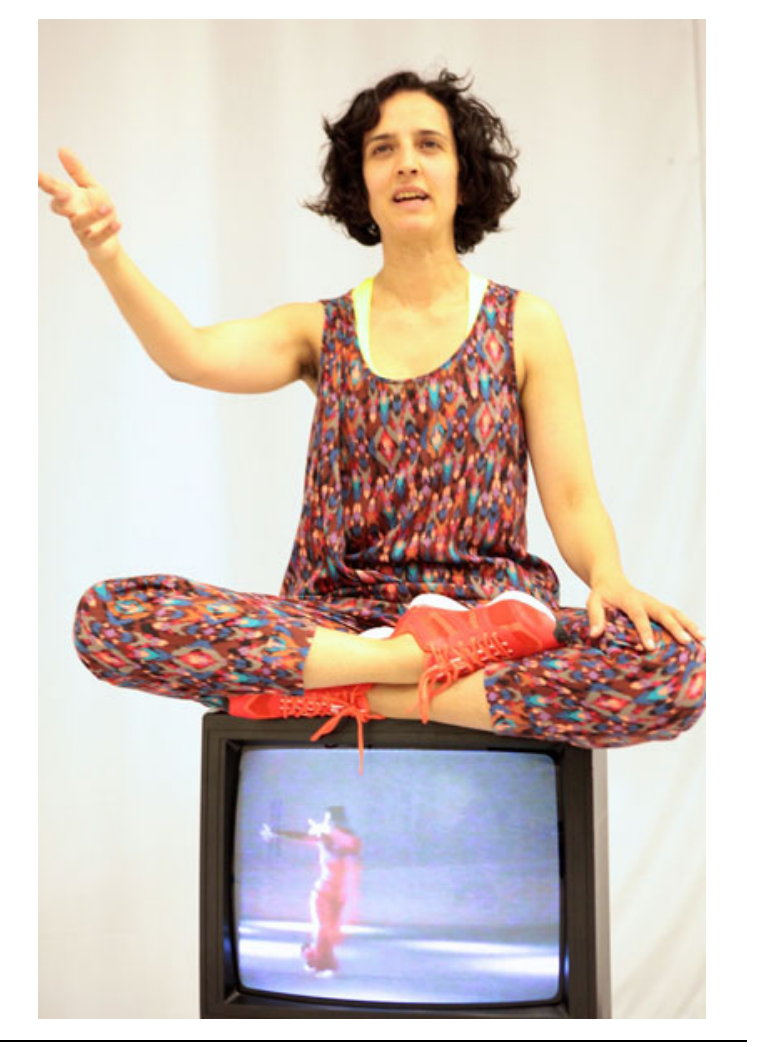

Photo 4. Future Memory: "Memory of Lila." Photo by Imre Zsibrik, 2012. rehearsal process, we clarified the terms of such interactions until the performance of inheritance developed a covert virtuosity. The "Memory of Lila" section, for example, was developed in several stages: initially, Nair was experimenting with watching the film and articulating what she saw; when I realized she could likely play the film in her head, I suggested she move from facing the television to standing behind it, so that that familiarity would be more legible; she then shifted herself to sitting on top. Rather than simply representing familiarity, however, the precision required from these tasks also opened up new levels in our understanding of the documentation material in the process. For example, Nair used to think Jooss was lying at points in the interview because of how difficult she found it to perform body language that did not match the spoken text, with gestures punctuating the speech in pauses or on unaccented syllables. But more recently Nair realized that, because Jooss is translating his thoughts in to English, his body reacts to what he has decided to say before he actually speaks. Her observation regarding the out-of-timeness of the translation underscored our sense of Jooss's strange out-of-placeness by the time of the interview-something we never mark explicitly, but which is nonetheless reinforced when a native-Swedish speaker takes on his German-accented English.

This casual intimacy extends to the other, more tangible things that Nair also inherited. The collection of Lilavati Häger's photographs, costumes, jewelry, and rehearsal tapes that Bengt Häger gave to her over the years are so familiar that when Nair's baby, crawling in the studio, began to teethe on Häger's snakeskin belt, friends joked she would grow up with history inside her. Initially this collection did not have a physical place in the performance itself, and yet its centrality to Nair's personal relationship with caring for Dixit Dominus made it important to include. Eventually we developed a bazaar-type exhibition scene in which she brings items out individually, displaying some from afar, stopping by small clusters of audience members to tell short stories about others. She comes out wearing a wig, holding Häger's clutch purse under her armpit, while she puts on the snakeskin belt and then Häger's favorite perfume, which wafts as she walks back and forth (Photo 5). She shows someone in the second row the sweat pads under the armpits of the costume Häger wore when filming Dixit for Swedish television, before leaving it with the audience member, returning ten minutes and two sections later to retrieve it. While an intimate performance facilitates such tactile strategies, Nair jokes that the version for a large-scale venue should involve a scent capable of being blown over the entire theater.

The use of these objects underscores some of the issues at stake in how Future Memory at times works against more traditional museal principles of preservation. ${ }^{9}$ There are a limited number of performances in which the perfume can be used. The liquid line in the Tabu bottle goes down each time Nair uses it, or she could spill it. But then again, it will likely eventually go stale or 
evaporate. The fabric of the costume is that fragile polyester of the late 1970s, which will corrode on its own, but this process is accelerated by the oils of audience members' hands. They grow careless after a while. One leans his forearms on the leotard that lies across his lap as he leans forward to watch the videotape in which Häger wears it. The perfume and the costume pose two different but related problems: first, if preservation only prolongs degradation, why police these items, in other words why not share them with the largest possible number of people before they are gone? And second, what happens if you trust people, even temporarily, with the costume or with the diamond ring that Nair leaves in the space- a gift from Bengt Häger for her first Dixit performance? Clearly objects like the costume and the bottle, unlike the sensory impressions or even the perfume, will (hopefully) return to Nair by the end of the evening, albeit with a bit more wear and tear. Yet what happens with them counters any presumption that caring for these things would mean squirreling them away in a protected location, held for registered users in numbered boxes to be handled only while wearing white gloves. If the work of the piece is about inheritance, then this suggests an archive that is kept in circulation by entrusting it to others, even if that risks the possibility of change.

\section{Reworking Contested Legacies}

Future Memory joins many other performances on contemporary European stages that draw on German dance, which itself has a particularly problematic legacy of rewriting and forgetting over the past hundred years. One of the terms still most common with regard to German modern dance history, Ausdruckstanz, did not come into regular usage until the early postwar era, at which time it was meant to reimagine a set of practices from the early twentieth century. ${ }^{10}$ More than a terminological technicality, this renaming also involved designating a story of inclusion and exclusion. As I have argued elsewhere, Jooss is a critical figure to historicizing the connections between earlier twentieth-century German modern dance and Tanztheater. He is often taken up as both a central and yet simultaneously exceptional figure, because his absence from Germany for nineteen years has been foundational to various narratives of continuity that short-circuit dance's development under the Third Reich. Whereas in the late 1940s and early 1950s, Jooss's work was described by many critics as an unfinished form of late Ausdruckstanz, by the 1970s and 1980s, his place as a precursor to Tanztheater was ensured by arguments that the political charge of his work distinguished him from those bracketed as Ausdruckstanz practitioners. ${ }^{11}$

Susan Manning recently pointed out that German dance has spent so much time dealing with its relationships to fascism, that it seems to now be acceptable to once again overlook this in favor of 
other questions deemed to be more urgent. For her, the current disinterest in the connections between Ausdruckstanz and National Socialism is less a disavowal than a consensus that has closed the topic until future researchers return to the archive to ask new questions in new ways (Manning 2012). Such inquiries do not have to be separated. Seen differently, archive-based experimental dance practices might themselves not only function as aesthetic exploration but also provide new ways for considering such contested legacies. Each time that they revisit the past, they have the potential not only to play within what they consider to be a commonly accepted narrative of the dance historical canon, but also to expose its gaps and discontinuities through their labor of re-doing.

The three projects that have garnered the most attention in recent years for reworking the materials of German dance history on contemporary concert stages are Martin Nachbar's affects/rework and Urheben Aufheben, both based on Dore Hoyer's 1962 Affectos Humanos; Fabian Barba's A Mary Wigman Dance Evening based on Wigman's first U.S. tour in 1930-1931; and Olga de Soto's An Introduction and Débords. Reflections on the Green Table, both based on Jooss's famous piece from 1932. Even as I collect them under their German referents, I want to mark an internationalism in how the majority of these choreographers encountered their practices in other places. Nachbar is German. De Soto is Spanish, trained in France, but working in Belgium. Barba is Ecuadorian but began his project in school in Belgium. And Nair is Swedish but met Häger while working in England. Each artist foregrounds his or her labor of engaging with these past practices. De Soto makes visible the usually hidden work of dance history by discussing onstage her research process or using her performers to stage the projection of "testimonies" about The Green Table that she has collected from former dancers and spectators. Nachbar not only recounts the ordeal of learning Hoyer's work from Waltraud Luley, but also sets up performances that highlight what it takes to inhabit the foreignness of an older physical technique. Barba's work is the most naturalized: his effort of performing Wigman becomes most apparent when an audience member takes one of the many candelabra-lit interludes to reflect on how uncannily effortless his performance is.

While all three engage with a family of works from within the same half-century, their projects propose different relationships to that history. Nachbar has written about his collaborators' interest in Affectos Humanos: "Besides Pina Bausch, we hardly knew anything about German Ausdruckstanz and its influences, and we were curious to find out how choreographers of this tradition had worked, and had approached the body as a tool of expression" (2012, 8). Likewise, Barba proposes that his reenactment work with Mary Wigman should "find its place among other attempts to analyze the tradition of Ausdruckstanz" $(2011,86)$. However, while Barba informs his reconstructions through the Ecuadorian dance practices already in his body, using their affinities to Ausdruckstanz to propose alternative linkages $(2011,84,87-9)$, Nachbar's process of learning what he identifies as Ausdruckstanz material in a body trained for release technique has to do with the possibilities and limits of citation. There are also moments that more explicitly revise dance history. For example, when Barba appears in de Soto's Débords, our identification of him with Wigman as a performer in "Jooss's" piece brings together the two opposed progeny of Rudolph Laban's teaching.

The danger in such projects that draw upon twentieth-century German dance, Future Memory included, is that their return to a problematic past risks strengthening, rather than mitigating, dominant narratives. The creative work in the present may ultimately take an ahistorical turn, flattening certain temporal economies that should remain destabilized, even as it disrupts others. This concern is raised by Jens Giersdorf, who uses the celebration of Nachbar's work by West German dance scholars to argue that such reconstructions reinforce the erasure of East German dance from the historical canon $(2013,86)$. Giersdorf points out that Nachbar's work tends only to be framed in terms of the previous 1988 reconstruction by West German choreographer Susanne Linke, not the one that East German Arila Siegert did in the same year. Giersdorf calls for the need to go beyond an aesthetic and methodological analytic frame in order to understand the 
ideological ramifications of such projects of redoing. At the same time, he suggests that the artistic work may prohibit accounting for larger ideological structures, since it is, in fact, supported by them. ${ }^{12}$

While addressing the precariousness of reworking contested legacies, it is important to mark that it is not only the German but also the Indian strands of Dixit Dominus that have their own histories of reconstruction, with the invention of "classical Indian dance" forms starting in the early twentieth century. As Pallabi Chakravorty puts it, Indian classical dance must itself be seen as a "revivalist and reconstructive movement" (2000/01, 110). Avanthi Meduri further argues for the inadequate binaries of any tradition/change model, because all "traditional practitioners" should themselves be seen as "inside-outsiders" negotiating the "burden of the reinvented past" $(2004,21)$. Häger herself was raised amid this history; she describes names critical to remaking Indian dance as regular visitors in her childhood home because her father brought Anna Pavlova to India, whose story intertwines with such figures as Uday Shankar (Häger 1984).

These histories matter in the context of European performances working with the past, where, as Hardt points out, ethnographic tradition tends to be aligned with the past versus the avant-garde with the new (2011). Whereas the distinction between, for example, art and heritage may tend, as Hardt suggests, to mean one thing in the context of a concert stage, in the twentieth-century construction of the "tradition" of classical Indian dance, the hereditary performers were those displaced. ${ }^{13}$ The project of interweaving Western and non-Western practices, both past and present, within the implicitly uneven power structures of the contemporary European theatrical milieu ${ }^{14}$ can be further destabilized by thinking in terms of reconstructions of reconstructions in order to keep in play the slipperiness of referents once multiple invented traditions are taken into account, each of which was itself developed through a layered process.

Such complexity is also necessary for understanding the collaboration between Häger and Jooss (Photo 6). Häger was famous in Sweden by the time of Dixit Dominus, with countless photos depicting her in high society, including alongside the king, while ladies' magazines published features on her domestic life, which, as Nair points out, were probably the only time she ever held a kitchen implement. The qualifications of the phrase that often comes up_ “'our' Lilavati” or "our Indian Lilavati" (for example Sjögren 1975, and Westerberg in Jooss 1977)—are telling; no matter how well known she was, her status as a non-white foreigner meant that she was excluded from the position of being unquestionably "ours." At the same time, Häger both capitalized on and

Photo 6. Kurt Jooss and Lilavati Häger, after a performance by Häger, likely 1970s. Courtesy of Rani Nair.

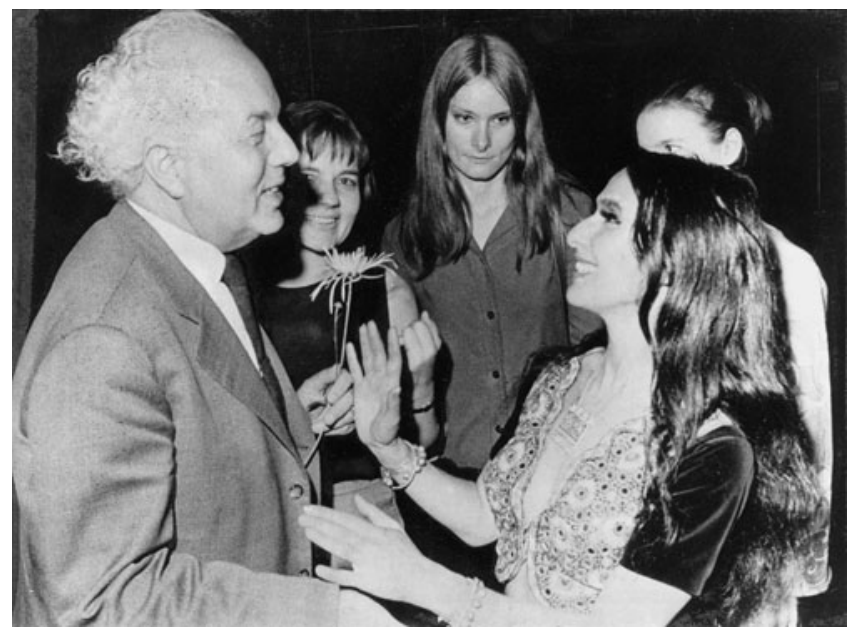


re-negotiated the mythology of her identity onstage and off. It is important to mark that Häger's interest in Jooss making a dance for her was part of her larger trajectory of experimentation between Indian and European forms. Newspaper clippings from the period before Dixit show a range of activities including choreographing a Scheherazade in Malmö in 1969-a performance with strange racial politics that was described as "the first time an Indian dancer uses her own technique for a great Western ballet" (Ståhle 1969)—and participating in an "East Meets West" concert tour in 1972, in which she shared a bill with Jean Cebron and Pina Bausch. ${ }^{15}$ Hammergren describes the tension between Häger's performances that relied “on a 'cosmopolitan' consciousness typical of the time" and the solo work "in which she kept more strictly to Indian dance forms, usually a combination of Bharatanatyam, Manipuri, and Kathak dances." And yet, despite the lack of closure that Häger maintained about her own background, Hammergren points out that she never articulated the more Westernized elements of her work in terms of diasporic identity $(2009,24-$ 26)..$^{16}$

However, early on, I had to convince Nair that it was too easy to place Jooss as the patriarchal foil for Häger, because both collaborators were outsiders in their own ways, verbally included in their respective "homes," but always as "other." Despite Jooss's privileged place in German dance history, once Jooss returned to Germany from exile in England, the company he had been promised, which only had its first performance in 1951, lost funding in 1953. Speaking with Bengt Häger around the time of Dixit, Jooss described hopes and promises being repeatedly "dissolved into nothing" on his return, until he was too old. He explained that he did what he could, but "After the war, when I came back to Germany I thought I would have become a sort of artistic leader in questions of ballets. But that did not happen because I was a refugee. I came as a stranger and remained a stranger. Nothing doing" (Jooss/Häger 1975, tape 15b, 21:26). In the interview that Nair voices-the one in which his body and speech are out of time-Jooss says that he wanted to "withdraw" as a choreographer for various reasons, a carefully chosen and emphasized word (1977). He broke this withdrawal to make Dixit with Häger. The piece was conceived while listening to music in a car and made over a short time in the Swedish seaside resort town of Tylösand on the body of a friend whose training was very different than his and yet who was also simultaneously central and exceptional. While Dixit Dominus has been seen as far from pivotal to Jooss's legacy, it seems significant to ask why this was the work that allowed him to return briefly to choreography after his role as a historical figure rendered him out of place in the present. At the same time, understanding how such a piece came to be written off as "minor" may reveal certain biases that support dance's histories. What myths of continuity would be disrupted by giving more weight to Jooss's legacy beyond Green Table, not just as a pedagogue but as a choreographer? Could doing so draw attention to the way his centrality in German dance history required situating him as exceptional, in a manner that ultimately displaced him from the very canon he supported? How would this story change, were Dixit not to be seen within modernism's ubiquitous orientalism, but rather as a collaboration that could only have happened between two artists who understood what it meant to be insiders and outsiders at the same time?

Something that comes up for us often is how to contextualize this project theatrically, because audience members will likely come with no prior knowledge of Dixit Dominus itself, although some may recognize Häger or Jooss. As the performance artists Janez Janša write: "In reconstructions, one first needs to prove that the object of a reconstruction actually existed" $(2012,368)$. One of the things we are careful with in Future Memory is not to show photographs or film until two-thirds of the way through the piece. Were the images to appear too soon, they would serve as a container for audience imaginations, whereas we challenge those watching to construct new images from the pieces we give them. We also wait until post-show to project a layered film of Nair and Häger both dancing Dixit. In addition, even when working with what is already a "minor" work, Future Memory explores paths not taken. For example there is the moment when Nair creates a ghost dance using a hairdryer on the silk haute couture costume that was made for Häger by a famous designer, but never worn in performance (Photo 7). Future Memory, then, is a chance to both question old stories and tell new ones. 


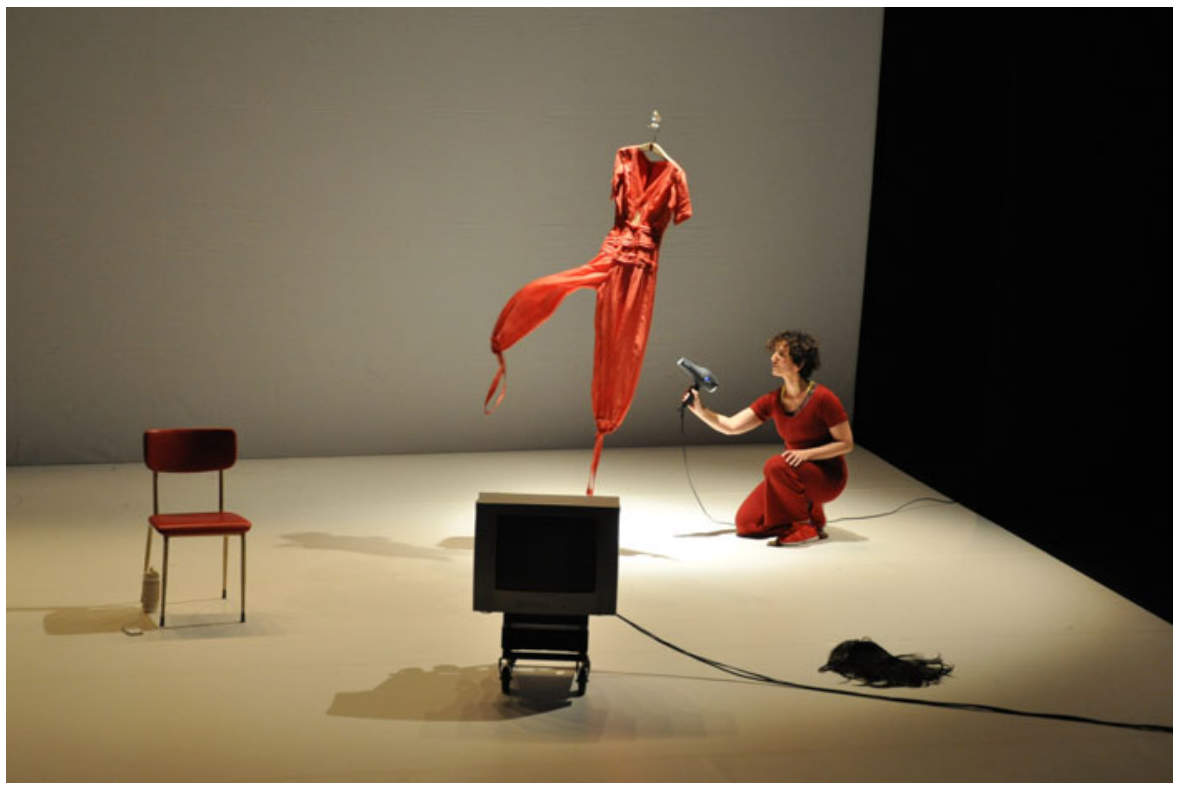

Photo 7. Nair uses a hairdryer to animate the spotlit haute couture costume that Häger never wore on stage. Performance photo by author, 2014.

\section{On Tangling with Histories: Reconstructing Reconstructions on a Global Stage}

In the letter she reads onstage, Nair asks Häger: "Did you give up the fusion of Western contemporary dance and traditional Indian forms? I remember Bengt saying something about you feeling that you'd failed in challenging the traditional form or finding a new approach to Indian dance." Later, during the verbatim interview, Nair gives voice to Jooss's explanation of Dixit Dominus as an attempt to make "something which was modern European but at the same time did not neglect or contradict Indian traditional ideas of movement." He described Häger as a "Hindu dancer with lots of European leanings," yet when pushed by the interviewer to articulate how Häger's background as an Indian dancer fit his choreographic style, he refused finite distinctions between the practices, explaining that "it fits into my choreography because my choreography fits into her" (Jooss/ Westerberg 1977). One of Nair's goals for Future Memory was to realize what that kind of fusion might look like today. There are two explicit dance sections in which she experiments with contemporary forms of Dixit. One takes its starting point from particular moments of Dixit, such as the slicing arms that she thinks might have been Häger's favorite movement ("I picture her cutting the heads off demons," Nair explains during the "Memory of Lila" section), the gesture's articulation of the ribs and shoulder girdle gradually developing into a broader range of arm-initiated possibilities, performed in silence for the length of the first section of the music. The other section is set to the rehearsal audio cassette tape, but draws on Dixit's movement material only in fits and starts. However, it would be a mistake to locate hybridity in those moments alone, rather than seeing the piece in its entirety as a container for larger questions of conjunction and dislocation-one that not only comments on such concerns but also absorbs them into its own project. Creating such a space that preserves difference, while allowing for shades of Indianness, Swedishness, and Germanness, is particularly important for us in working with Dixit Dominus and its many protagonists, times, and places.

In a recent article on the contemporary "global stage," Ananya Chatterjea posits that the power dynamics of hybrid forms are often disguised by the erasure of difference: "What seems to be 
increasingly popular in the sphere of Asian 'contemporary' dance is a kind of ventriloquism, where contemporary Asia finds its voice through signifiers of the Euro-American modern/ postmodern, the latter passing once again as the neutral universal, which is able to contain all difference" $(2013,11)$. By contrast, one of Nair's starting points had to do with too much difference; she wanted to know whether anything she could do would always be marked as "Indian" within Swedish dance, or whether she could push the limits of movement and embodiment toward a more ambiguous legibility, in which multiple practices interrelate without either entirely revealing themselves or dissolving into one another. ${ }^{17}$ Hammergren has written about the difficulty of classifying Europe and India separately in Dixit Dominus because of their status as lived geographies (2009). Such undoing of presumed monocultures is something that Sandra Chatterjee is now extending through research that places both Dixit and Future Memory within a larger project on "kinesthetic entanglements" between Indian and Northern European practices on contemporary dance stages. ${ }^{18}$ However, I think that one of the key elements to marking, and thus exposing, the kind of "difference" to which Ananya Chatterjea refers is crossing this geo-political with the temporal dimension. In Future Memory, what Nair calls the "classical Indian dance" is a loose mixture of physical practices, including Kathak, Bharatanatyam, and various yogas in which she has trained and performed in Sweden, the UK, and India in the past two decades. ${ }^{19}$ By contrast, Nair's referent for "contemporary dance" (Dixit) is tied to a specific time and place that appears anachronistic in the present-a dance by an aging modernist choreographer in a postmodern age.

Nair and I talk about how to present a dance that is out of time without being nostalgic or a museum piece on the one hand, while also not erasing its difference on the other. If "classical Indian dance" is for Nair a more universal signifier than the already-then-out-of-date particularities of a 1975 "contemporary" dance collaboration (which already aimed to bring together the two), then it seems there might be a way for the future promise of the piece to fix and release ideas of tradition-both Indian and European-by understanding both to be deeply unstable, and working into those instabilities. When Nair started trying to place Dixit Dominus, one of the things that troubled her was how it stood outside the progress narrative of dance history. Yvonne Rainer's 1966 Judson classic Trio A, for example, preceded Dixit by a decade and yet felt more familiar. Nair also began by articulating the power structures of who choreographed whom; but the longer she worked with the piece, the more her assumptions were undone. The footwork, for example, that she initially presumed was a contribution from Häger, started to feel more Joossian. Around the time of a showing in Hamburg at Kampnagel's P1 space in 2010, she was still reaching for the Western dance history canon to anchor this difference, for example transitioning from flat-footed stamps-somewhere between a Bharata Natyam solo and role of Death in The Green Table - into the toe-taps of Trio A.

It was not until 2012 that Nair began to play with the mixture of practices that coexisted within her own body, neither flattening or smoothing them to a continuous whole, nor allowing clear distinctions to emerge. The improvisational process that she calls "contemporary Indian dance" developed as a container that allows for abrupt shifts between performance registers that are accessible within her corporeal archive: a lunge that hops up and down to a gesture in which the hands each make small circles with two fingers pointed out, as she leans into a hip; a neck circle becomes a full-body gyration. The purpose of the practice is to disrupt flow, using the body to hijack messages sent from the brain and vice versa. ${ }^{20}$ This practice solved the problem of the rehearsal tape at the end of Future Memory (Photo 8). By now, Nair's multicolored jumpsuit is covered by the version of the red costume that she had commissioned to dance Dixit Dominus while pregnant at Bengt's funeral. She listens to a mixed playlist through wireless headphones, while the audience hears the Dixit rehearsal tape with Jooss's elegant voice counting and singing over the music that comes from the miked tape recorder. The television is paused on "Dixit Dominus." Nair's dance sometimes meets up with the rehearsal tape; at times the timing between the two is syncopated, at others they are simply in parallel worlds altogether. Nair takes the microphone with her when she leaves the stage after the first section of the music, but leaves the cassette playing. By the time the sound returns from the 

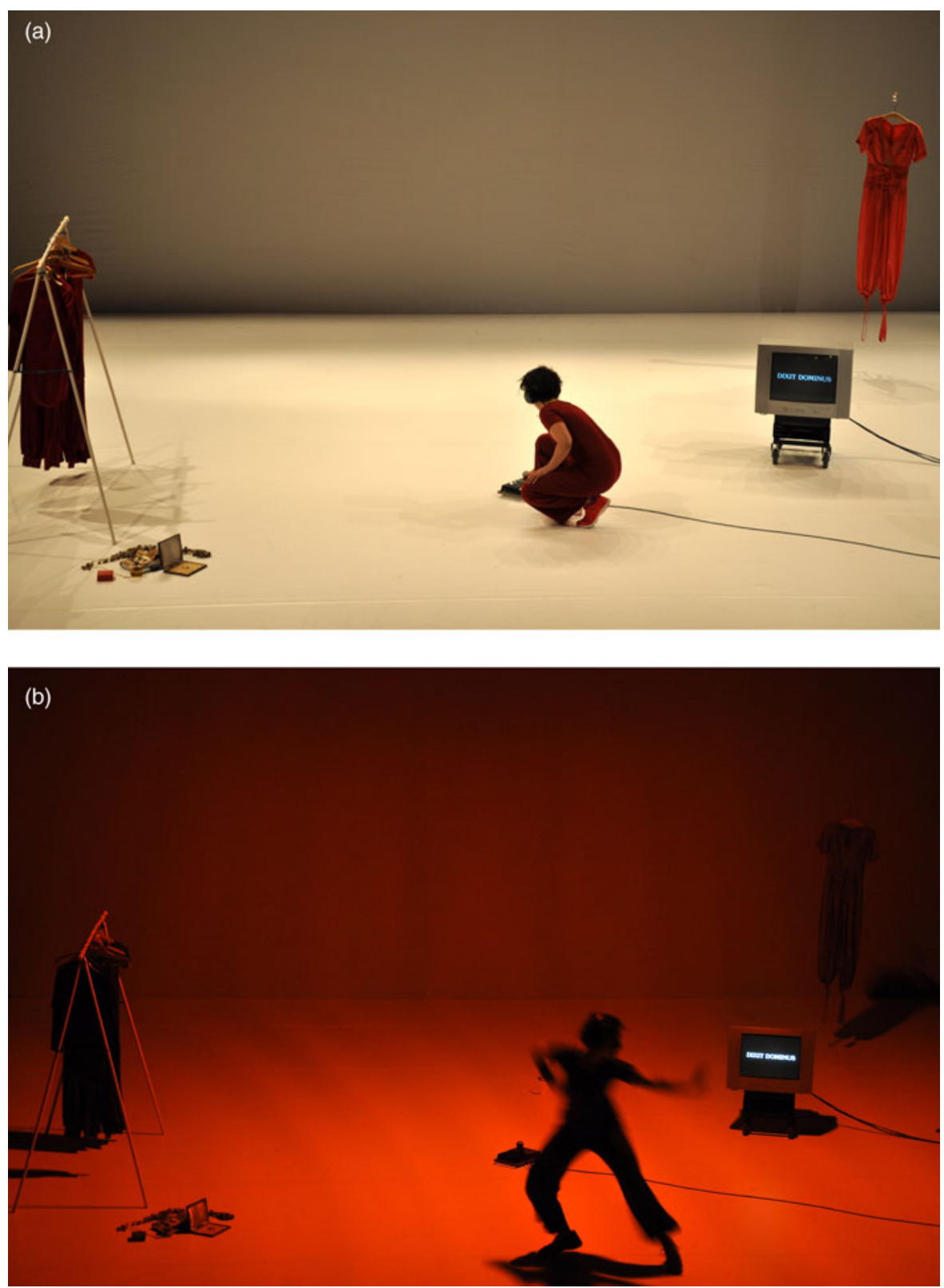

Photo 8. In the final section, Nair places a microphone on the tape recorder, amid the larger stage installation that has accumulated, and then begins the "contemporary Indian dance," illuminated by a sodium lamp. Performance photos by author, 2014.

theater's speakers to the tape recorder to finish out the second part, I can only hear it in conjunction with the different ways that Nair had inhabited the now-empty stage.

This historical dimension - thinking through the temporal other in relation to racial or spatial complications of otherness-is crucial to the piece's "future" potential. Early in making Future Memory, Nair was taken by the "Altermodern Manifesto," Nicholas Bourriaud's proposition for a form of recycling and reuse that responds to "a new globalized perception" (2009a). The "altermodern" articulates a "concept of wandering-in time, space and mediums" (Bourriaud in Ryan 2009). In this sense, it speaks to Future Memory's promiscuous use of performance registers, its investment in translation, as well as the multiple times and places that overlap within it in a manner that does 
not strictly reinforce a narrative of the colonial West. However, there is an extreme presentism to Bourriaud's insistence that the cultural and social structures in which we live are nothing more than information to be translated, transcoded, and reassembled. By contrast, Future Memory not only "produces a singular itinerary within different knowledge streams" (Bourriaud in Ryan 2009), but also, in so doing, reveals the ways in which those streams as already "entangled," as Gorän Therborn would put it, in a manner that not only coexists in the present, but also draws on more durational historical relationships $(2003) .{ }^{21}$ It is by revealing such entanglements that their wanderings suggest new paths, routes between and beyond the more familiar canon in which Dixit Dominus has little place. To wander into this piece in isolation and then back out again would be to miss the opportunities it offers to reflect back and, in so doing, ahead.

While Bourriaud is interested in singularity $(2009 \mathrm{~b}, 13)$, other scholars have shown the potential in approaching global memory with a sense of historical specificity. This is particularly important in a German context, where memory has itself been so contested as to become, as Andreas Huyssen puts it, a "particularly ubiquitous cipher for memories of the twentieth century," focusing local discourses internationally $(2003,18$, 98). Michael Rothberg, for example, argues for the need to recognize the borrowing and cross-referencing of "multidirectional memory," a "convoluted, sometimes historically unjustified, back-and-forth movement of seemingly distant collective memories in and out of public consciousness," whose imaginative links have the potential to produce new objects and perspectives (2009, 17-19). Likewise, Huyssen argues that, while memory discourses may appear global, they are at their core still tied to the histories of specific nation states, and can thus also help develop new forms of grounding in an increasingly globalized world. However, in order for them to do so, he cautions that we need to recognize what is happening and how, rather than simply celebrating instability and in-betweenness: "Memory as re-presentation, as making present, is always in danger of collapsing the constitutive tension between past and present... . Thus we need to discriminate among memory practices in order to strengthen those that counteract the tendencies in our culture to foster uncreative forgetting, the bliss of amnesia, and ... 'enlightened false consciousness"' (Huyssen 2003, 10). ${ }^{22}$ Both Huyssen and Rothberg ultimately suggest that new futures come from understanding how multiple pasts continue to be asked to work in the present, often in unexpectedly intersecting ways that help to articulate one another.

Coming full circle, Huyssen's imperative to distinguish is crucial for Hardt's suggestion that what is happening on European stages is a performative means of "doing history" in the playground of the past-a way not only to ask what kinds of history are being done, but also what that doing does or can do. One of the things we have struggled with most in Future Memory is how far we can go in pushing toward something "new" when the referent exists in so few people's consciousness. Huyssen prompts us to think more specifically about what creative practices do when they do history. Are they telling stories about the constructedness of historical materials, which are ultimately rooted in the present? Or might even those belong to a set of formative stories of place and thus speak to more durational and specific entanglements? If so, how can we still deal with the ways in which multiple othernesses may help to articulate one another? The thing that I am coming to terms with through Future Memory is how to think in a manner that is at once global and historically specific, the stakes of reinserting temporal and geopolitical groundings even as boundaries are crossed in creative ways that help us to remember alternative histories and, through them, other futures.

\section{Notes}

This article is part of a larger writing project related to Future Memory, supported by the Lilian Karina Foundation's 2013 Research Grant in Dance and Politics. An extended version of this essay is forthcoming in The Oxford Handbook of Reenactment, edited by Mark Franko. 
1. In Sweden, she was primarily known by her first name alone ("Lilavati") or by the stage name she sometimes used, "Lilavati Devi."

2. Jooss made dances through 1966 and then stopped. He continued to do some choreography for theatrical productions through 1972. See the full register of works in Stöckemann (2001). While Dixit was made in 1975, it did not premiere until later.

3. In addition to the many essays that have filled the pages of Dance Research Journal, a compilation of artists' writings and scholarship from performance can be found in Perform, Repeat, Record, edited by Amelia Jones and Adrian Heathfield (2012).

4. Whereas Foster sees this to offer new possibilities of order at the same time as it suggests failures in larger structures, André Lepecki (2010) responds that such work should be seen not to originate from loss, but from a more excessive impulse to explore the abundant immanent possibilities.

5. Just as my thoughts take part in shaping the work that Nair performs on stage, what is here on paper owes so much to our conversations, as well as those with others that she has recounted to me, all of which are an ongoing part of her inheritance. Because my participation was first as a dramaturg and historian for the project, but only years later as also a writer, I treat exchanges from within our collaboration in a practice-based, rather than ethnographic, manner.

6. As well as being published in Ful (Nair 2010) and presented on their own as readings, some of these letters also appear as part of Future Memory, read aloud by Nair as well as audience members.

7. After its December 2012 premiere in Malmö, Future Memory has since appeared elsewhere in Sweden, including being chosen for the Scenkonstbiennalen in Jönköping. Its first run in a larger theater was at Dansens Hus (House of Dance) in Stockholm in March 2014, where it was programmed alongside Olga de Soto's An Introduction.

8. In addition, neither the piece nor Lilavati Häger herself appears in the index of names and works, although Bengt Häger does (Stöckemann 2001, 463-76).

9. Critiques regarding hierarchies of transmission have often been grounded in non-Western or disenfranchized perspectives, catalyzing around questions of who controls the archive and the more mutable ways in which memory is understood to be stored, transformed, and passed on. To name just a few of many possible examples: Diana Taylor builds her distinction between the "archive" and the "repertoire" through an argument that exploring the transmission of knowledge in the form of embodied action "decenters the historic role of writing introduced by the Conquest" $(2003,17)$; Priya Srinivasan argues for the need to use "kinesthetic history" in order to show the interactions of multiple laboring bodies and thus complicate binary judgments regarding orientalism (2012, 72); and David Román suggests that instances of "archival drag" exceed the static capacities of more traditional archival systems, such as museums or libraries, when "embodied archival systems" based in queer communities pass and transform the work through affect and interest $(2005,165,174)$.

10. This term and our understandings of the practices to which it refers have been revised substantially over the past few decades, beginning with the conference that led to the edited collection Ausdruckstanz: eine mitteleuropäische Bewegung der ersten Hälfte des 20 Jahrhunderts (OberzaucherSchüller 1992), and continuing with discussions including the relationships between Ausdruckstanz and Tanztheater, its relationships to German fascism, and its transnational connections. On the historicization and reinvention of Ausdruckstanz, see Franco (2007) and Elswit (2014). For a general overview of German dance in the immediate aftermath of World War II, see Müller, Stabel, and Stöckemann (2003).

11. On Jooss's return and the postwar reception of his Green Table in West Germany, see the chapter on "Watching After Weimar: Dance's Intellectual Property and the Protection of Memory" in Elswit (2014). On the problem of exiles being out of time, see Elswit (2012).

12. He suspects that Nachbar cannot reference Arila Siegert as "it would force him to leave the confines of his own aesthetic and his notion of dance history, because Siegert does not appear in it. Siegert seemingly fails on an aesthetic level and does not exist in historical terms" (Giersdorf 2013, 107). 
13. This in turn was reflected in how Indian dance practices appeared in diasporic communities. On how the negotiation of "traditional" and "modern" played out in American diasporic communities, see Srinivasan (2012), and in British communities, see Lopez y Royo (2004). On the displacement of hereditary performers, see Peterson and Soniji (2008, 7, 20).

14. See, for example, Savigliano's argument about "World Dance" as already fusion (2009, 177).

15. A review from this concert tour produces a fascinating observation in retrospect: at the time, Häger, was better known to Swedish audiences than Cebron and Bausch (Ståhle 1972).

16. Hammergren also historicizes Häger's later career, pointing out that the intercultural projects were subsequently overshadowed by a return to a more mythologized India-as-origin.

17. This project follows several of Nair's earlier works including Pepparkakeland (2007), which more explicitly took up such questions regarding the legibility of racialized bodies in a contemporary Swedish cultural context.

18. Chatterjee's work is ongoing as part of the FWF Project "Traversing the Contemporary (pl.): Choreographic Articulations between European and Indian Dance" (P24190), conducted at the Department of Music and Dance Studies, Paris Lodron University, Salzburg, Austria.

19. In some senses, this is not so distant from Häger, who worked in a more pan-stylistic Indian mode like Ram Gopal, with whose company she first came to Sweden.

20. Because a full "contemporary Indian dance" performance for Nair would need to be at least half an hour (more like the length of a conventional ballet), she sees the improvisation at the end of Future Memory to be a form of place-holder for that possibility, rather than a fully realized version.

21. For a useful overview of discussions on alternative, hybrid, and multiple modernities, and what they each offer up to scholarly thought, see Grossberg (2010).

22. The timing noted in other fields for the turn from "history" to "memory" also coincides with the first round of modern dance's reconstructions (see Franko 1989).

\section{Works Cited}

Angström, Anna. 2014. "Rani Nair skapar laddad dialog om att ärva ett danssolo." Svenska Dagbladet. March 15. Available online at http://www.svd.se/kultur/scen/rani-nair-laddar-solomed-smarta-perspektivbyten_3367538.svd.

Barba, Fabian. 2011. "Research into Corporeality." Dance Research Journal 43(1): 82-89.

Bourriaud, Nicolas. 2009a. “Altermodern Explained: Manifesto.” Tate Britain. Accessed January 13, 2009. http://www.tate.org.uk/whats-on/tate-britain/exhibition/altermodern/explain-altermodern/ altermodern-explainedmanifesto.

—. 2009b. The Radicant. Translated by James Gussen and Lili Porten. New York: Lukas \& Sternberg.

Chakravorty, Pallabi. 2000/01. "From Interculturalism to Historicism: Reflections on Classical Indian Dance." Dance Research Journal 32(2): 108-119.

Chatterjea, Ananya. 2013. "On the Value of Mistranslations and Contaminations: The Category of 'Contemporary Choreography' in Asian Dance.” Dance Research Journal 45(1): 7-20.

de Soto, Olga. 2012. "Olga de Soto about 'Débords. Reflections on The Green Table” [Interview with Andrea Keiz]. Accessed June 16, 2013. http://vimeo.com/49506237.

Elswit, Kate. 2012. "Back Again? Valeska Gert's Exiles.” In New German Dance Studies, edited by Susan Manning and Lucia Ruprecht, 113-29. Champaign, IL: University of Illinois Press.

- 2014. Watching Weimar Dance. New York: Oxford University Press.

Foster, Hal. 2004. "An Archival Impulse." October 110 (Fall): 3-22.

Franco, Susanne. 2007. “Ausdruckstanz: Traditions, Translations, Transmission." In Dance Discourses: Keywords in Dance Research, edited by Susanne Franco and Marina Nordera, 80-98. London: Routledge.

Franko, Mark. 1989. "Repeatability, Reconstruction and Beyond.” Theatre Journal 41(1): 56-74. 
Giersdorf, Jens Richard. 2013. The Body of the People: East German Dance Since 1945. Madison, WI: University of Wisconsin Press.

Grossberg, Lawrence. 2010. Cultural Studies in the Future Tense. Durham, NC: Duke University Press. Häger, Lilavati, and Lars Ulvenstam. 1984. Filmed Television Interview for "Nyfiken på” series. ID\# 30131. Sveriges Television AB.

Hammergren, Lena. 2009. "The Power of Classification." In Worlding Dance, edited by Susan Leigh Foster, 14-31. New York: Palgrave Macmillan.

Hardt, Yvonne. 2011. "Staging the Ethnographic of Dance History: Contemporary Dance and Its Play with Tradition." Dance Research Journal 43(1): 27-43.

- 2012. "Engagements with the Past in Contemporary Dance." In New German Dance Studies, edited by Susan Manning and Lucia Ruprecht, 217-231. Champaign, IL: University of Illinois Press.

Huyssen, Andreas. 2003. Present Pasts: Urban Palimpsests and the Politics of Memory. Stanford, CA: Stanford University Press.

Janša, Janez. 2012. "Reconstruction2: On the Reconstuctions of Pupilija, Papa Pupilo and the Pupilceks." In Perform, Repeat, Record: Live Art in History, edited by Amelia Jones and Adrian Heathfield, 367-83. Bristol, UK: Intellect Books.

Jones, Amelia, and Adrian Heathfield, Eds. 2012. Perform, Repeat, Record: Live Art in History. Bristol, UK: Intellect Books.

Jooss, Kurt, and Bengt Häger. 1975. [Unpublished interview tapes]. Carina Ari Library, Stockholm. Jooss, Kurt, and Stig Westerberg. 1977. "Dixit Dominus" [filmed television interview]. Sveriges Television AB, December.

Lepecki, André. 2010. “The Body as Archive: Will to Re-Enact and the Afterlives of Dances." Dance Research Journal 42(2): 28-48.

Lopez y Royo, Alessandra. 2004. "Dance in the British South Asian Diaspora: Redefining Classicism.” Postcolonial Text 1(1), [online] http://postcolonial.org/index.php/pct/article/ viewArticle/367/809.

Manning, Susan. 2012. "Looking Back Again, and Again” [unpublished lecture]. Journée d’Étude: Autour de l'historiographie de la danse moderne allemande: état de lieux et perspectivesm, University of Nice Sophia Antipolis, March 29.

Meduri, Avanthi. 2004. "Bharatanatyam as Global Dance: Some Issues in Research, Teaching, and Practice.” Dance Research Journal 36(2):11-29.

Müller, Hedwig, Ralf Stabel, and Patricia Stöckemann, Eds. 2007. Krokodil im Schwanensee: Tanz in Deutschland seit 1945. Frankfurt am Main, Germany: Anabas-Verlag.

Nachbar, Martin. 2012. “Training Remembering.” Dance Research Journal 44(2): 5-12.

Nair, Rani. 2010. “RANI <3 LILAVATI FRÅN 1975 TILL 2020.” Ful 2. Available online at http:// www.tidskriftenful.se/mag.php? $\mathrm{m}=$ ful\&issid=1292059906\&text $=1339153154$.

Oberzaucher-Schüller, Gunhild, Ed. 1992. Ausdruckstanz: eine mitteleuropäische Bewegung der ersten Hälfte des 20 Jahrhunderts. Wilhelmshaven, Germany: Florian Noetzel Verlag.

Peterson, Indira Viswanathan, and Davesh Soniji. 2008. "Introduction." In Performing Pasts: Reinventing the Arts in Modern South India, edited by Indira Viswanathan Peterson and Davesh Soniji, 1-42. New York: Oxford University Press.

Pikula, Joan. 1981. “Kurt Jooss's Dixit Dominus for Lilavati.” Dance Magazine (August): 54-56.

Román, David. 2005. Performance in America: Contemporary U.S. Culture and the Performing Arts. Durham, NC: Duke University Press.

Rothberg, Michael. 2009. Multidirectional Memory: Remembering the Holocaust in the Age of Decolonization. Stanford, CA: Stanford University Press.

Rubidge, Sarah. 1995. "Reconstruction and Its Problems." Dance Theatre Journal 12(1): 31-33.

Ryan, Bartholomew. 2009. "Altermodern: A Conversation with Nicolas Bourriaud." Art in America.

March 17. Accessed October 30, 2013. http://www.artinamericamagazine.com/news-features/ interviews/altermodern-a-conversation-with-nicolas-bourriaud/

Savigliano, Marta. 2009. "Worlding Dance and Dancing Out There in the World." In Worlding Dance, edited by Susan Leigh Foster, 163-90. New York: Palgrave Macmillan. 
Siegmund, Gerald. 2010. "Affekt, Technik, Diskurs: Aktiv Passiv Sein im Angesicht der Geschichte.” In Original und Revival: Geschichts-Schreibung im Tanz, edited by Christina Thurner and Julia Wehren, 15-26. Zürich: Chronos.

Sjögren, Margarete. 1975. "En ny Balett av Kurt Jooss." Svenska Dagbladet. October 18.

Srinivasan, Priya. 2012. Sweating Saris: Indian Dance as Transnational Labor. Philadelphia: Temple University Press.

Ståhle, Anna Greta. 1969. "Exotiskt balettmöte I Malmö.” Dagens Nyheter. February 1. . 1972. "Öst och väst dansar på Scala." Dagens Nyheter. April 19.

Stöckemann, Patricia. 2001. Etwas ganz Neues muß nun entstehen: Kurt Jooss und das Tanztheater. München, Germany: K. Kieser Verlag.

Taylor, Diana. 2003. The Archive and the Repertoire: Performing Cultural Memory in the Americas. Durham, NC: Duke University Press.

Therborn, Göran. 2003. “Entangled Modernities.” European Journal of Social Theory 6(3): 293-305. 